\title{
Sesame sowing date and insecticide application frequency to control sesame webworm Antigastra catalaunalis (Duponchel) in Humera, Northern Ethiopia
}

\author{
Zenawi Gebregergis ${ }^{*}$, Dereje Assefa ${ }^{2}$ and Ibrahim Fitwy ${ }^{2}$
}

\begin{abstract}
Background: Sesame (Sesamum indicum L.) is one of the most important crops in Ethiopia for international market, while its production is challenged by insect infestations and inappropriate agronomic practices. Sesame webworm (Antigastra catalaunalis) is the major pest, which causes heavy losses in Humera areas, Northern Ethiopia. This study aims to determine optimum sowing time and insecticide application frequency for controlling A. catalaunalis.
\end{abstract}

Results: The results showed that the early sowing gave minimum infestation of sesame webworm and better sesame grain yield. The integration of early sowing and weekly spray (T16) resulted in low incidence (8.8\%) and higher grain yield $(651 \mathrm{~kg} / \mathrm{ha}$ ), where the combination of late sowing and untreated (control) plot (T3) gave higher incidence (100\%) and lower grain yield (69.1 kg/ha). The maximum level of leaf, flower and capsule damage was scored on the late sowing and untreated plot, while the lowest was in the early sowing and weekly sprayed plot.

Conclusions: Planting sesame early on the onset of rainfall followed with two application of insecticide at 2 and 4 weeks after emergence was found economical and optimum management option for controlling A. catalaunalis.

Keywords: Sesamum indicum, A. catalaunalis, Capsule damage, Incidence, Insecticide frequency

\section{Background}

Sesame (Sesamum indicum L.) is an annual plant that belongs to the Pedaliaceae family. It is one of the world's oldest oil seed crop grown mainly for its oil-rich seeds [1]. Although the order of leading sesame producing countries is changing from time to time, Ethiopia is the sixth largest sesame producer in the world following Myanmar, India, China, Sudan and Tanzania, and third in Africa followed by Uganda and Nigeria. Of the total world production of sesame, the top 5 countries account over $64.3 \%$ [2].

The Ethiopian whitish Humera-type variety is known for its taste (sweetness) in the world market; hence, it is exported to the confectionary market where

\footnotetext{
*Correspondence: zenawigg@gmail.com

${ }^{1}$ Tigray Agricultural Research Institute, Humera Agricultural Research

Center, P.O. Box 62, Humera, Ethiopia

Full list of author information is available at the end of the article
}

white-seeded types are demanded by the consumers [3] The four major sesame growing regions in the country are mainly Tigray, Amara, Oromia and Benishangul Gumuz. Within Tigray, western zone is the main sesame production area with large commercial farms and many smallscale farmers, and sesame is a good source of income in these areas, but there are many hurdles for its production and productivity such as limited research endeavor in plant protection aspects, lack of economically feasible and technically appropriate production technologies. In the study area, a research on integrated managements of major sesame pests has been not conducted yet.

Insect pests such as sesame webworm (Antigastra catalaunalis), sesame seed bug (Elasmolomus sordidus), and gall midge (Asphondylia sesami) are the most important insects that affect production of sesame. Out of which sesame webworm (A. catalaunalis) is the most important insect that affects sesame during various growth stages 
starting from 2 or 3 weeks after emergence up to harvesting [4-10].

Objectives of this study were to estimate the optimum sesame sowing time and frequency of insecticide application to control sesame web worm and boost sesame yield.

\section{Materials and methods}

\section{Description of the study area}

A field experiment to investigate effects of sowing time and insecticide application frequency on A. catalaunalis infestation was conducted in western Tigray at Humera Agricultural Research Center (HuARC), which is located at latitude of $14^{\circ} 15^{\prime} \mathrm{N}$, longitude of $36^{\circ} 37^{\prime} \mathrm{E}$ and elevation of $608 \mathrm{~m}$. The experimental site, Humera, is under the administration of Kafta Humera (Fig. 1). The agroecology of the location is described as hot to warm semiarid plain with mean temperature of $29^{\circ} \mathrm{C}$, annual mean rainfall of $581.2 \mathrm{~mm}$ (which ranges from 380 to $870 \mathrm{~mm}$ ), verti soil, $\mathrm{PH}$ value of 8.4 and husbandry variations.

\section{Experimental design}

The experiment was done in factorial randomized complete block design (RCBD) with three replications. The path between blocks and plots was 2.5 and $2 \mathrm{~m}$, respectively. The net plot area was $9.6 \mathrm{~m}^{2}$. The total area of the experiment was $\left(2288 \mathrm{~m}^{2}\right)$. Sesame seeds were planted in $40 \mathrm{~cm}$ inter-row and $10 \mathrm{~cm}$ intra-row spacing.

\section{Sowing time}

Setit-1 variety was used as a test variety. Sowing date for sesame in the study area ranges from mid-June to midJuly [4]. Similarly, the New LocClim software (satellite data) provided that the second dekad of June as onset of rainfall for the study area (Humera) (Fig. 4). But Gebre et al. [11] reported that the onset date of rainfall in North Ethiopia for the last 30 years was significantly varied. And the same authors added that onset of rainfall in a specific location can be determined, when $20 \mathrm{~mm}$ or above of rainfall is recorded for three consecutive days for the main season (Kiremt). Therefore, accordingly, onset of rainfall was on July 12 and then first sowing (early sowing) was on July 13, second sowing (mid-sowing) on July 23 and third sowing (late sowing) on August 02.2015.

\section{Insecticide application frequency}

When the larva started detection in 2 WAE, dimethoate $40 \% \mathrm{EC}$ a broad spectrum pesticide was applied at a rate of $2 \mathrm{l} / \mathrm{ha}$ ( $800 \mathrm{~g}$ of active ingredient per hectare) according to the treatments under natural environment. The weekly spray (positive control) was started 1 week after emergence before start of $A$. catalaunalis infestation, and spraying was continued in interval of 1 week for ten consecutive weeks up to maturity. The insecticide application frequency includes: $0,1,2,3,4$, and 10 . The detail description is explained in Table 1. Hand-operated knapsack sprayer was used for dimethoate $40 \%$ EC application.

\section{Plant related data collection}

From the net plot area, five plants were selected randomly and tagged to collect the phenological, growth and yield component traits of sesame. Days to $50 \%$ flowering and $50 \%$ maturity were taken on plot basis. Furthermore, the eight experimental rows excluding both margins to reduce boarder effect were harvested, tied in sheaves and were made to stand separately until the capsules opened and threshed by knocking the sheaves and then weighed for yield determination.

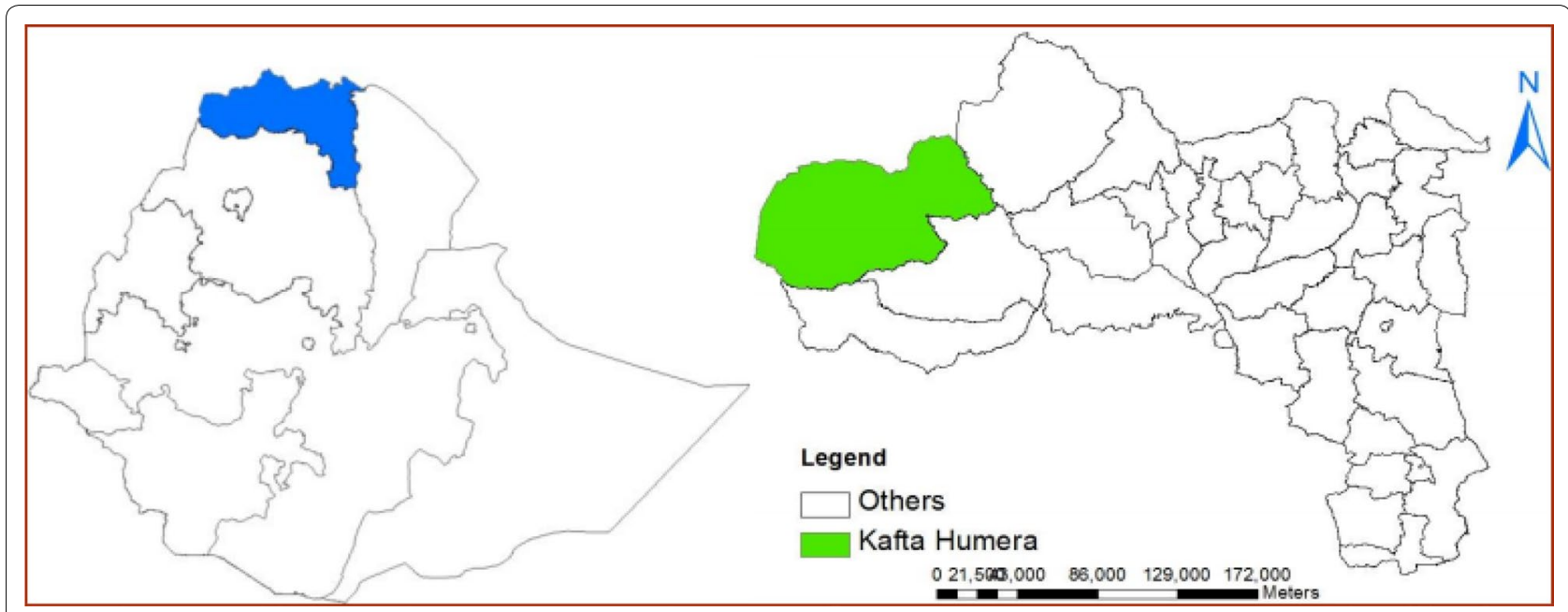

Fig. 1 Map of the study area 
Table 1 Treatment combination of sowing date and insecticide application frequencies

\begin{tabular}{llll}
\hline Treatments combination & Sowing dates & & Late sowing \\
\cline { 3 - 4 } & Early sowing & Mid-sowing & \\
Insecticide application frequencies & & $\mathrm{T} 2$ & $\mathrm{~T}$ \\
1. Control or untreated (F0) & $\mathrm{T} 1$ & $\mathrm{~T} 5$ & $\mathrm{~T}$ \\
2. Once @ 2-WAE (F1) & $\mathrm{T} 4$ & $\mathrm{~T} 8$ & $\mathrm{~T}$ \\
3. Twice @ 2 and 4-WAE (F2) & $\mathrm{T} 7$ & $\mathrm{~T} 11$ & $\mathrm{~T}$.2 \\
4. Thrice @2,4 and 6-WAE (F3) & $\mathrm{T} 10$ & $\mathrm{~T} 14$ & $\mathrm{~T} 15$ \\
5. Four times @ 2,4,6 and 8-WAE (F4) & $\mathrm{T} 13$ & $\mathrm{~T} 17$ & $\mathrm{~T} 18$ \\
6. Weekly spray (positive control) (F10) & $\mathrm{T} 16$ & & \\
\hline
\end{tabular}

\section{A. catalaunalis-related data collection}

- Incidence (INC \%): incidence of A. catalaunalis was recorded through total count of infected plants at any of plant part (leaf, flower and/or capsule) in the plot for six times on a fortnightly basis. It was calculated using the following equation:

Incidence $=\frac{\text { no. of infested plant }}{\text { total plant in the plot }} * 100$

- No. of larva (NLP): larvae were counted from five randomly selected plants per plot. It was counted six times in a fortnightly basis from the plants.

- Leaf damage (LD \%): leaves that have some symptoms of $A$. catalaunalis attack like bored and webbed leaves were taken as damaged leaves. Damaged leaves per plant were recorded from leaves of the five randomly selected plants, and they were counted six times on a fortnightly basis from leaves of the plants.

Leaf damage $=\frac{\text { no. of infested leaf }}{\text { total inspected leaves }} * 100$

- Flower damage (FD \%): webbed and tunneled flowers were considered as damaged flowers. Damaged flower per plant was recorded from flowers of the five randomly selected plants and it was counted three times on a fortnightly basis from flowers of the five plants.

Flower damage $=\frac{\text { no. of infested flower }}{\text { total inspected flowers }} * 100$

- Capsule damage (CD \%): all burrowed capsules were reserved as damaged capsules. Damaged capsules per plant were recorded from the five randomly selected plants and they were counted three times on a fortnightly basis from capsules of the five plants.

Capsule damage $=\frac{\text { no. of infested capsule }}{\text { total inspected capsule }} * 100$
- Seed loss of damaged capsule (SL \%): difference in the number of seeds of the healthy and damaged capsules was considered as a loss. A single damaged and healthy capsule was taken from the same node of the plant for each of the five randomly selected plants during harvesting and a number of seeds per each damaged and healthy capsules were counted. Seed loss was calculated as the following equation.

$\mathrm{SL} \%=\frac{\mathrm{NSPHC}-\mathrm{NSPDC}}{\mathrm{NSPHC}} * 100$

where $\mathrm{SL}=\%$ of seed loss of the damaged capsule, $\mathrm{NSPHC}=$ number of seeds per healthy capsule, NSPDC $=$ number of seeds per damaged capsule.

\section{Data analysis}

Collected data for the different traits of the designed field experiment were analyzed using computer statistical software Genstat 16. Means were compared using Duncan's multiple range test (DMRT), at $p$ level of 0.01 probability level.

\section{Results}

The incidence of $A$. catalaunalis was significantly different $(p<0.001)$ among all the three sowing dates. The number of larva per plant and incidence were significantly lower on the early sowing sesame than the late sowing. Insecticide application frequency showed also significant difference $(p<0.001)$ on $A$. catalaunalis incidence. The maximum incidence level (98.38\%) was detected on the control plot, which was in par with the once sprayed plot and lower $(26.10 \%)$ on the weekly sprayed plot (Table 2). The interaction effect between sowing date and frequency of insecticide application was highly significant $(p<0.001)$. Higher incidence $(100 \%)$ was recorded from the combination of late sowing and control plot, while the integration of early sowing and weekly spray (T16) scored lower (8.79\%) value (Table 3). 
Table 2 Main effect of sowing date and insecticide application frequency on A. catalaunalis infestation, yield and yield component of sesame

\begin{tabular}{|c|c|c|c|c|c|c|c|}
\hline Treatments & NLP & INC (\%) & LD (\%) & FD (\%) & $\mathrm{CD}(\%)$ & SL (\%) & GY (kg/ha) \\
\hline \multicolumn{8}{|l|}{ Sowing dates } \\
\hline Early sowing & $3.9^{\mathrm{a}}$ & $42.32^{\mathrm{a}}$ & $3.704^{\mathrm{a}}$ & $18.83^{\mathrm{a}}$ & $15.64^{\mathrm{a}}$ & $44.24^{\mathrm{a}}$ & $472.3^{c}$ \\
\hline Mid-sowing & $6.622^{b}$ & $48.71^{\mathrm{a}}$ & $4.519^{\mathrm{a}}$ & $26.88^{b}$ & $32.93^{b}$ & $49.92^{\mathrm{a}}$ & $355.7^{\mathrm{b}}$ \\
\hline Late sowing & $8.222^{c}$ & $73.34^{b}$ & $6.838^{b}$ & $36.31^{c}$ & $36.49^{b}$ & $63.57^{b}$ & $284.4^{\mathrm{a}}$ \\
\hline $\mathrm{SE}( \pm)$ & 1.81 & 12.993 & 2.025 & 7.523 & 5.507 & 16.471 & 34.569 \\
\hline CV (\%) & 29 & 23.7 & 40.3 & 27.5 & 19.4 & 31.3 & 9.3 \\
\hline \multicolumn{8}{|c|}{ Insecticide application frequencies $(F)$} \\
\hline F0 & $8.6^{c}$ & $98.38^{d}$ & $8.024^{b}$ & $39.77^{c}$ & $39.74^{c}$ & $87.3^{d}$ & $147.2^{\mathrm{a}}$ \\
\hline F1 & $8.289^{c}$ & $84.07^{c}$ & $6.426^{b}$ & $37.08^{c}$ & $34.15^{b}$ & $59.64^{c}$ & $239.5^{b}$ \\
\hline$F 2$ & $5.933^{b}$ & $43.33^{b}$ & $4.182^{\mathrm{a}}$ & $21.53^{\mathrm{a}}$ & $23.38^{\mathrm{a}}$ & $52.36 b^{c}$ & $432.6^{c}$ \\
\hline F3 & $6^{\mathrm{b}}$ & $35.41^{\mathrm{ab}}$ & $4.156^{\mathrm{a}}$ & $28.9^{b}$ & $25.96^{\mathrm{a}}$ & $45.54^{\mathrm{abc}}$ & $429.5^{c}$ \\
\hline F4 & $5.178^{a b}$ & $41.44^{b}$ & $3.885^{\mathrm{a}}$ & $17.92^{\mathrm{a}}$ & $25.49^{\mathrm{a}}$ & $40.63^{\mathrm{ab}}$ & $444.9^{c}$ \\
\hline F10 & $3.489^{\mathrm{a}}$ & $26.1^{\mathrm{a}}$ & $3.448^{\mathrm{a}}$ & $18.82^{\mathrm{a}}$ & $21.41^{\mathrm{a}}$ & $30.01^{\mathrm{a}}$ & $531.2^{d}$ \\
\hline $\mathrm{SE}( \pm)$ & 1.81 & 12.993 & 2.025 & 7.53 & 5.507 & 16.471 & 34.569 \\
\hline CV (\%) & 29 & 23.7 & 40.3 & 27.5 & 19.4 & 31.3 & 9.3 \\
\hline
\end{tabular}

Means followed by same letter are significantly not different

$\mathrm{INC}=$ incidence, $\mathrm{NIL}=$ number of infected leaf per plant, $\mathrm{LD}=$ leaf damage, $\mathrm{TL}=$ total leaf, $\mathrm{NLP}=$ number of larva per plant

Table 3 Interaction effect of sowing time and insecticide application frequency on $A$. catalaunalis infestations

\begin{tabular}{|c|c|c|c|c|c|}
\hline Treatments & INC (\%) & FD (\%) & CD (\%) & SL (\%) & GY (kg/ha) \\
\hline \multicolumn{6}{|l|}{ Early sowing } \\
\hline $\mathrm{FO}$ & $95.88^{\text {hi }}$ & $32.11^{\mathrm{cd}}$ & $31.61^{\mathrm{b}-\mathrm{e}}$ & $76.59^{\text {de }}$ & $217.4^{c}$ \\
\hline F1 & $81.94^{g h i}$ & $29.7^{c d}$ & $22.59^{b}$ & $69.18^{\text {cde }}$ & $310^{\text {de }}$ \\
\hline $\mathrm{F} 2$ & $20.1^{\mathrm{ab}}$ & $10.89^{\mathrm{ab}}$ & $10.56^{\mathrm{a}}$ & $34.5^{\mathrm{ab}}$ & $539.6^{h}$ \\
\hline F3 & $24.12^{\mathrm{ab}}$ & $24.07^{b c d}$ & $12.44^{\mathrm{a}}$ & $38.09^{b c}$ & $534.5^{h}$ \\
\hline F4 & $23.06^{\mathrm{ab}}$ & $10.59^{\mathrm{ab}}$ & $11.76^{\mathrm{a}}$ & $39.6^{b c}$ & $581^{h}$ \\
\hline F10 & $8.79^{a}$ & $5.59^{\mathrm{a}}$ & $4.85^{\mathrm{a}}$ & $7.49^{\mathrm{a}}$ & $651^{i}$ \\
\hline \multicolumn{6}{|l|}{ Mid-sowing } \\
\hline FO & $99.27^{i}$ & $36.59 d^{e}$ & $38.12^{\text {cde }}$ & $91.46^{\mathrm{e}}$ & $154.9^{b}$ \\
\hline F1 & $78.67^{g h i}$ & $33.29^{\mathrm{cd}}$ & $38.99^{\mathrm{de}}$ & $33.86^{\mathrm{ab}}$ & $260^{\mathrm{cd}}$ \\
\hline $\mathrm{F} 2$ & $36.31^{\mathrm{bcd}}$ & $25.97^{\mathrm{cd}}$ & $29.58^{\mathrm{bcd}}$ & $58.93^{\mathrm{bcd}}$ & $391.1^{\mathrm{fg}}$ \\
\hline F3 & $27.49^{a b c}$ & $25.43^{c d}$ & $27.16^{\mathrm{b}}$ & $41.48^{b c}$ & $368.6^{\mathrm{efg}}$ \\
\hline $\mathrm{F} 4$ & $30.99^{\mathrm{abc}}$ & $20.38^{b c}$ & $32.01^{\mathrm{b}-\mathrm{e}}$ & $41.81^{b c}$ & $422.9^{9}$ \\
\hline F10 & $19.5^{\mathrm{ab}}$ & $19.61^{b c}$ & $31.74^{\mathrm{b}-\mathrm{e}}$ & $32.01^{\mathrm{ab}}$ & $536.6^{h}$ \\
\hline \multicolumn{6}{|l|}{ Late sowing } \\
\hline $\mathrm{FO}$ & $100^{i}$ & $50.6^{f}$ & $49.48^{f}$ & $93.86^{e}$ & $69.1^{a}$ \\
\hline F1 & $91.59^{g h i}$ & $48.25^{\mathrm{ef}}$ & $40.87^{\mathrm{ef}}$ & $75.86^{\mathrm{de}}$ & $148.6^{b}$ \\
\hline $\mathrm{F} 2$ & $73.56^{\mathrm{fgh}}$ & $27.72^{\mathrm{cd}}$ & $30.01^{\mathrm{bcd}}$ & $63.64^{b-e}$ & $366.9^{\text {efg }}$ \\
\hline F3 & $54.61^{\mathrm{def}}$ & $37.2^{\text {de }}$ & $38.27^{\text {de }}$ & $57.06^{\mathrm{bcd}}$ & $385.4^{\mathrm{fg}}$ \\
\hline F4 & $70.27^{\mathrm{efg}}$ & $22.8^{\mathrm{bcd}}$ & $32.69^{b-e}$ & $40.49^{b c}$ & $330.7^{\mathrm{ef}}$ \\
\hline F10 & $50^{\text {cde }}$ & $31.26^{\mathrm{cd}}$ & $27.63^{b c}$ & $50.54^{\mathrm{bcd}}$ & $405.9^{9}$ \\
\hline $\mathrm{SE}( \pm)$ & 12.993 & 7.523 & 5.507 & 16.471 & 34.569 \\
\hline CV (\%) & 23.7 & 27.5 & 19.4 & 31.3 & 9.3 \\
\hline
\end{tabular}

Means followed by same letter are significantly not different, INC $=$ percent of A. catalaunalis incidence per plant, $\mathrm{FD}=$ percent of flower damage per plant, $\mathrm{CD}=$ percent of capsule damage per plant, $\mathrm{SL}=\%$ off seed loss per damaged capsule, $\mathrm{GY}=$ grain yield
In comparison with early sowing higher leaf, flower and capsule damages were scored on the late sowing sesame. About 6.8, 36.3 and 36.5\% leaf, flower and capsule damages, respectively, were recorded on the late sowing. Sowing time has also significant effect on seed loss per damaged capsule, the early planting contributed $19.3 \%$ reduction in seed loss compared to late planting (Table 2). With regard to the effect of insecticide application frequency, there was a minimum damage of leaf, flower and capsule on the weekly sprayed plots. When effects of the interaction between sowing time and insecticide application frequency were examined, late sowing and control (T3) was found to have the maximum level of flower and capsule damage. The interaction effect also revealed that the combination of early sowing and weekly spray (T16) was lower (7.49) in seed loss per damaged capsule, while late sowing and control (T3) was higher (93.86\%) (Table 3).

Sowing date, insecticide application frequency and their interaction have showed a significant $(p<0.001)$ variation on yield and yield components of sesame. Comparatively higher grain yield $(472.3 \mathrm{~kg} / \mathrm{ha})$ was harvested on the early sowing sesame, while the lower $(284.4 \mathrm{~kg} / \mathrm{ha}$ ) was on late sowing (Table 2). Regarding to insecticide application frequency, better grain yield $(531.2 \mathrm{~kg} / \mathrm{ha})$ was harvested on the weekly sprayed plot, while the control plot produced lower $(147.2 \mathrm{~kg} / \mathrm{ha})$ yield (Table 2). The permutation of early sowing and weekly spray (T16) has higher grain yield $(651.0 \mathrm{~kg} / \mathrm{ha})$ corresponding to the late sowing and control $(69.1 \mathrm{~kg} /$ ha) (Table 3). 


\section{Discussion}

Incidence of $A$. catalaunalis was severe on late sowing sesame. Early sowing has about $73.3 \%$ reduction in incidence of $A$. catalaunalis compared to late sowing (Table 2). This indicates that the pest might be in favor of green cover (weeds) and high temperature to rear and reproduce prior to infest sesame. And early in the season (July), there were no weeds. Low temperature and high rainfall were also observed in July and August, while high temperature and low rainfall were in September and October (Fig. 2). Higher infestation of the pest was also observed late in the season on the late sowing. And the pest's preference is fleshy and young growing points (leave, flower, capsules). Therefore, reproductive stage of the early sowing sesame has already completed before $A$. catalaunalis population get raised, where the late sowing sesame has not escaped. This work is in line with Egonyu et al. [12] who reported that sowing the crop during the onset of rainfall (may) had less infestation of $A$. catalaunalis than planting late in the season. Similarly, Ahirwar et al. [13] reported that high temperature $\left(>27^{\circ} \mathrm{C}\right)$ and low rainfall ( $<200 \mathrm{~mm}$ monthly rainfall) during flowering and pod formation stages aggravate the incidence of the pest. Many Indian researchers reported that the pest is active from August to November [13-15] and early sowing (June) sesame is less infested than late sowing sesame. Hence, sowing the crop early in the season enabled the crop to escape from sesame webworm damage, while the delayed sowing resulted in a significantly higher level of damage to leaves, flowers and pods. This could be associated with the fact that the maximum number of larval population and incidence is strongly correlated with maximum temperature and lower rainfall $[13,14]$.

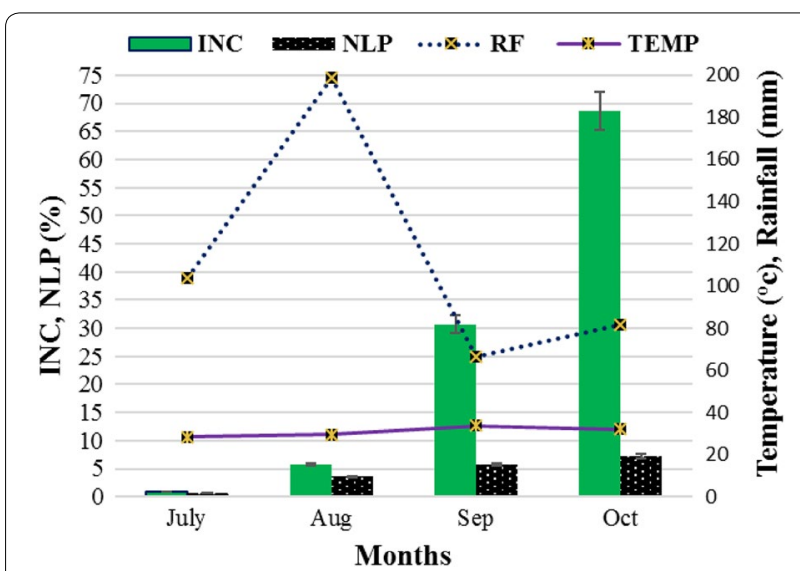

Fig. 2 A. catalaunalis incidence across the growing season (months) in 2015. INC= incidence (\%), NLP = number of larva per plant, $\mathrm{RF}=$ monthly total rainfall $(\mathrm{mm}), \mathrm{TEMP}=$ monthly average temperature $\left({ }^{\circ} \mathrm{C}\right)$
Frequencies of the insecticide application have a significant variation on controlling $A$. catalaunalis. The weekly sprayed plot has $73 \%$ reduction in incidence of the pest in comparison with the control (Table 2). Of course, the pest and its incidence could not be totally avoided, but its incidence could possibly lower to 26 and 56\% through weekly spray and twice @ 2 and 4-WAE spray. Application of endosulfan $0.07 \%$ at 30 and 45 days after planting was proved to be the most effective at controlling A. catalaunalis [15]. The early sowing and scheduled insecticide application has showed low incidence of the pest compared to late sowing and untreated plot. Combination of early sowing and weekly spray has about $91 \%$ reduction in $A$. catalaunalis incidences over the late sowing and untreated plot (Table 3). Pest incidence across growth stages of sesame have increased from about $5 \%$ at seedling stage ( $2 \mathrm{WAE}$ ) to more than $65 \%$ at capsule development stage (8-10 WAE) and the number of larva per plant has significantly increased from 2.6 at seedling stage to 6.3 at capsule development (Fig. 3a). When incidence across months during sesame growing season is detected, there was less than $1 \%$ incidence in July (seedling) but reached about $70 \%$ in October (capsule development stage) (Fig. 2). The marked increase in the pest incidence in October (capsule development) could be due to favorable environment like higher temperature, lower rainfall and higher sunshine hours in October (Figs. 2, 4). Zerabruk [16] noted that a maximum mean incidence percentage of sesame webworm was recorded at the end of September during pod setting. A. catalaunalis infestation was reported to be higher during capsule formation phase of the crop than vegetative growth and flowering stages [17]. On the other side, Kumar et al. [18] reported that a strong correlation between the larval population, maximum temperature, maximum relative humidity and limited rainfall. Similarly, incidence of A. catalaunalis was higher in dry sunny weather conditions than in wet weather condition and an outbreak of the pest occurred when a long dry spell had been preceded by heavy rains [19]. Same author added that there was a positive correlation between the abundance of the months and the number of hours of sunshine.

Higher damage of sesame plant part has been recorded on the late sowing, while early planting has fewer damage. Reproductive parts of sesame have severely damaged by the pest compared to the leaves. In the same fashion, higher damage $(6-12 \%)$ caused by $A$. catalaunalis was recorded on reproductive parts of sesame, while low (4\%) on leaves [16]. Similarly, Choudhary et al. [20] noted that higher level of capsule damage (40\%) and lower leaf damage from untreated sesame plot. A. catalaunalis infests sesame flowers more than the pods, but can cause up to $53 \%$ seed loss in pods [21]. Karuppaiah and Nadarajan 

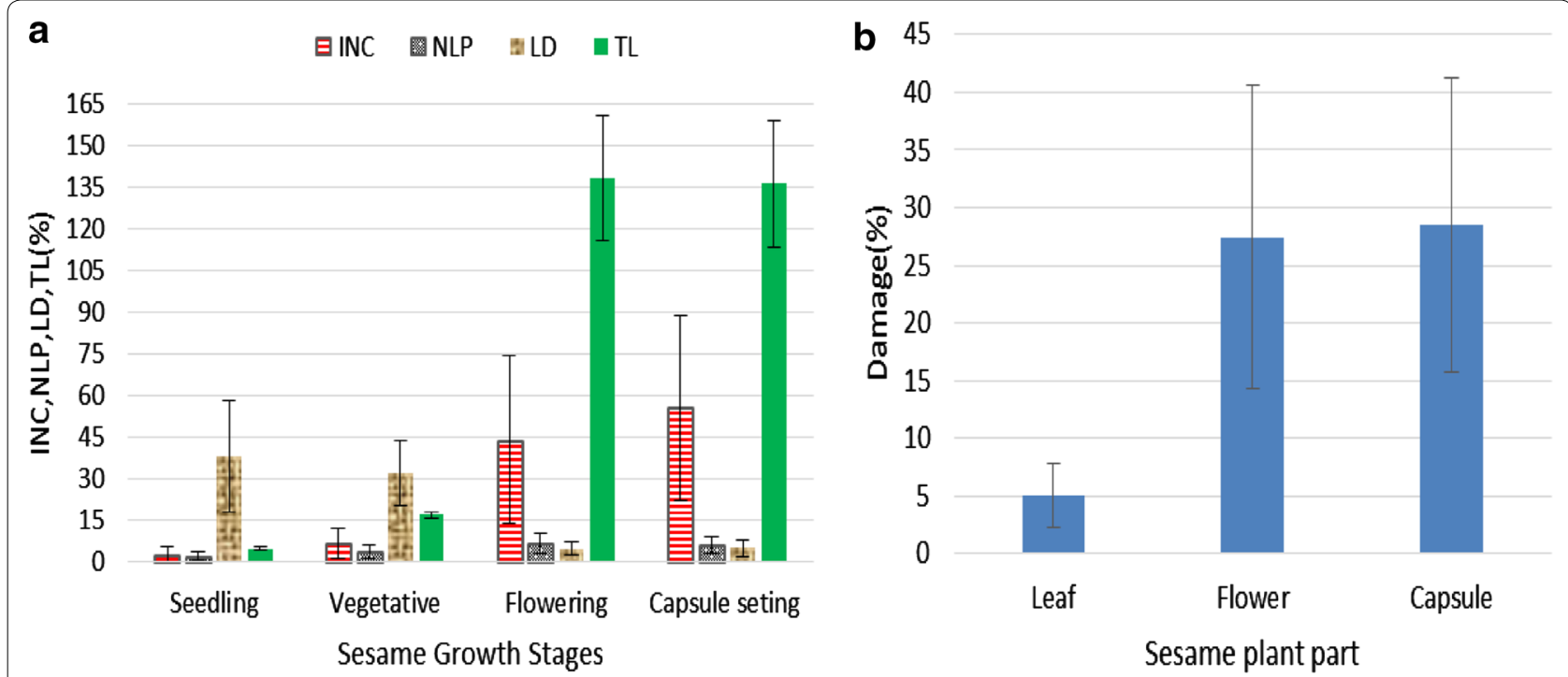

Fig. 3 A. catalaunalis incidence across sesame growth stages (a) and severity of damage across plant parts (b). INC = incidence, NIL = number of infected leaf per plant, $L D=$ leaf damage, $T L=$ total leaf, $N L P=$ number of larva per plant

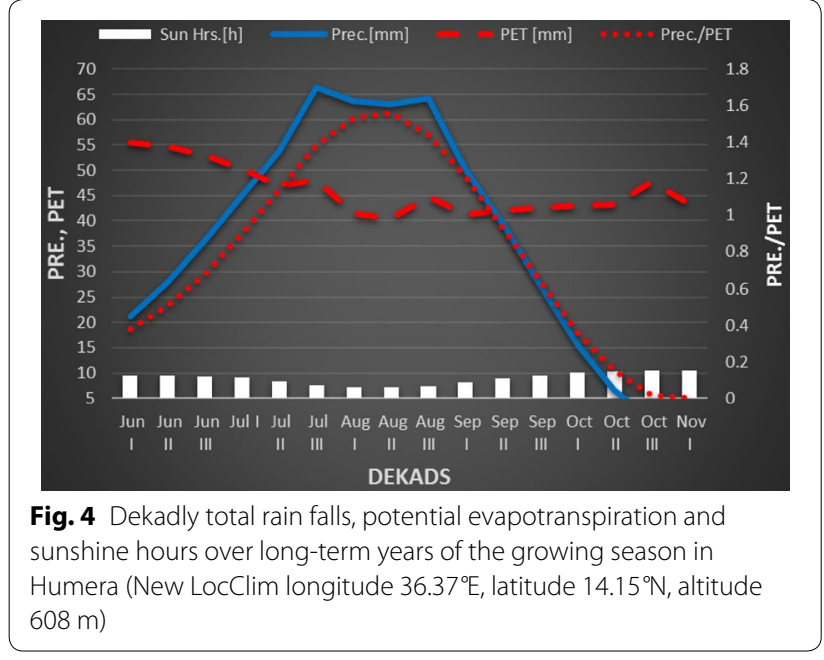

[14] reported that, when infestation occurs at very early stage, plant dies without producing any capsule and shoot growth was affected, when infestation occurred at later stages. Planting sesame during June and July escaped from damage and delay in sowing resulted in a significantly higher level of damages to leaves, flowers and pods [22]. Similarly, Abdalla and Mohamed [23] reported that infestation of $A$. catalaunalis in late sowing was higher than early sowing (17.8 larvae/25 plants in August 1 and 21.1 larvae/25 plants in August 15). Methods of assessing yield loss are usually based on the degree of infestation and seed loss in pods. The higher damage of leaf $(8.1 \%)$, flower (39.8\%) and capsule (39.7\%) was recorded on the control (untreated), and it was significantly similar with the one-time-sprayed plots. Minimum percent of seed loss per damaged capsule (30.0\%) was calculated on the weekly sprayed plot, while the maximum percent of seed loss per damaged capsule (87.3\%) was from the untreated plot (Table 2) and Simoglou et al. [24] estimated more than $50 \%$ of seed losses. Thus, it could be noted that the frequent insecticide spray had less leaf, flower and capsule damage and reduced seed loss. Similarly, Egonyu et al. [12] and Karuppaiah [22] reported that application of insecticides twice at 2-3 and 4-5 weeks after sesame emergence was effective and economical to control $A$. catalaunalis. Similar works reported that flower and capsule damages caused by $A$. catalaunalis were significantly controlled, when endosulfan was sprayed three times [25]. Moreover, application of spinosad $0.001 \%$ two times has significantly reduced larval population, and flower and capsule damage compared to control [26]. As illustrated in (Fig. 3b), severity of damages of sesame plant parts has varied from $5 \%$ on leaf to $28 \%$ on reproductive parts. Similarly, Karuppaiah and Nadarajan [14] have reported that $32.67 \%$ flower damage and $24.69 \%$ capsule damage as caused by $A$. catalaunalis. Therefore, flower and capsule were the most exposed sesame parts to damages by $A$. catalaunalis. But this might not be always true because of two reasons: (1) The higher level of damages on flower and capsule could be due to the favorable weather conditions (higher temperature and low rainfall) during the reproductive stage of the plant, and the pest likely prefers feeding on the young and soft plant parts. (2) The lower level of damages on leaves was not because 
of low infestation of the pest recorded on the leaves; instead, it was due to the higher number of total leaves per plant, which definitely lowered the value.

When leaf damage across different growth stage of the plant was detected, more damage was observed on the young growth stage. Leaf damage was higher $(43.11 \%)$ at seedling stage, while it was lower (5.34\%) at the capsule developmental stage. And this is an antagonistic to the A. catalaunalis incidence recorded, which was ultimately increased from seedling to capsule development stage. But the fact behind the lower leaf damage was the sharp increment of total leaf number per plant (denominator during calculation of leaf damage) from fewer leaves (4.78) during seedling to large number of leaves (136.6) at capsule development stage (Fig. 3a).

Early sowing of sesame was performed than the late and mid-sowings. The early sowing might get an advantage of the earlier moisture for emergence and might escape from infestation of the pest. Several research outcomes witnessed that adjusting time of planting often helps crops to escape the vulnerable crop stage from an insect pest and also to harvest better grain yield [27-29]. Higher sesame grain yield (1172 kg/ha) was harvested in Metema, North Ethiopia, when sesame was planted early in the season, and lower $(200 \mathrm{~kg} / \mathrm{ha})$ yield from late sowing [30]. Regardless of sowing time, insecticide application frequencies have great impacts on the grain yield differences. Two and more than two times sprayed plots have showed less incidence and severity, while the control and one-time-sprayed plots were higher in incidence and severity caused by $A$. catalaunalis. The fact behind the higher capsule per plant and grain yield on the frequently sprayed plots could be the presence of healthy leaf and flower, which can ahelp to bear more fertile capsules. On the other way, in the control plot there was higher damage of leaves and flowers that possibly reduced the number of healthy capsules. Muez [31] reported that higher yield $(714 \mathrm{~kg} / \mathrm{ha})$ of sesame was recorded from dimethoate $40 \%$ EC-treated plot. In the same way, three times spraying of $0.07 \%$ endosulfan significantly reduced the capsule damage caused by $A$. catalaunalis and also increased the grain yield of sesame [25]. Higher grain yield of sesame $(809 \mathrm{~kg} / \mathrm{ha})$ was harvested from insecticide-treated plot and lower $(594.5 \mathrm{~kg} / \mathrm{ha})$ from the untreated one [16]. Moreover, higher grain yield $(7.2 \mathrm{~kg} / \mathrm{ha})$ was recorded, when insecticide was sprayed two times at 3 and 6 WAE, and lower grain yield (4.1 kg/ ha) from the control [20].

The combined effect of early sowing and frequent insecticide sprays influenced the yield positively. When the yield of early sowing and weekly spray plot was compared with the late sowing and untreated plot, the later one has $89.4 \%$ of yield increment. Perhaps the early sowing might get an advantage from the early rains compared to the late sowing. In addition to that, the pest by its nature is not active during early sowings because of its preference to higher temperature and limited precipitation. And most of the weather conditions in the months of July and August were not conducive for the pest compared to September and October (Fig. 2). Moreover, the pest prefers feeding on the growing points of younger plants, because they are soft and easy for penetration and webbing. That's why, the most integrated treatments (early sowing and frequent sprays) resulted in reduced pest incidence and better grain yields. Result of this study is in line with Egonyu et al. [12] who reported that higher yield of sesame $(1039 \mathrm{~kg} / \mathrm{ha})$ was recorded from integration of early planting and scheduled application of insecticides at 2 and 4 WAE, while lower yield ( $175 \mathrm{~kg} / \mathrm{ha})$ was recorded from late planting with no insecticide application. Similarly, higher grain yield was recorded from the integrated application of early sowing and insecticide spray [30]. Spraying neem oil $1 \%$ or neem seed kernel extract $5 \%$ at the early stage of infestation reduced pest infestation and increased grain yield significantly [22]. The author also added that single control strategy may not give satisfactory control, while integrated strategies could give better control, better economic value and minimal environmental pollution. Khalid [32] reported that sesame webworm as a major pest of sesame in west Oromia, Ethiopia, causes substantial yield loss.

\section{Partial budget analysis}

Results of the partial budget analysis indicated that insecticide application at 2 and 4 WAE had the higher net profit and a corresponding marginal rate of return. The most frequently sprayed (weekly spray) plot has the least net profit due to the cost of the sprayed insecticide (Table 4). Therefore, application of dimethoate two times at 2 and 4 WAE had the higher net profit (USD 279.4) which clearly confirmed that application of insecticide at 2 and 4 WAE had the highest MRR (389.1\%) than all the other treatments.

\section{Conclusions}

Late sowing sesame is more infested with $A$. catalaunalis and has $66.1 \%$ yield reduction compared to early sowings. Sesame webworm population buildup has dramatically increased from seedling stage to capsule developmental stage of the crop and caused substantial yield loss. Application of insecticide two times at 2 and 4 WAE has $66 \%$ of yield advantage compared to the untreated plot. And integration of the early sowing with two times insecticide spray at 2 and 4 WAE has good control of A. catalaunalis and extends the grain yield advantage to $89.4 \%$ in comparison with the late 
Table 4 Partial budget analysis for insecticide application frequency on $A$. catalaunalis

\begin{tabular}{|c|c|c|c|c|c|c|c|}
\hline \multirow[t]{2}{*}{ S/no } & \multirow[t]{2}{*}{ Cost-benefit data } & \multicolumn{6}{|c|}{ Insecticide application frequency (F) } \\
\hline & & Fo & F1 & F2 & F3 & F4 & F10 \\
\hline 1 & Yield kg/ha & 132.48 & 215.5 & 389.4 & 386.5 & 400.4 & 478.1 \\
\hline 2 & Price USD/kg & 0.9 & 0.9 & 0.9 & 0.9 & 0.9 & 0.9 \\
\hline 3 & Total revenue USD/ha $\left(1^{*} 2\right)$ & 116.3 & 189.3 & 341.9 & 339.4 & 351.6 & 419.8 \\
\hline 4 & Total input cost USD/ha & 0.0 & 31.2 & 62.4 & 93.7 & 124.9 & 312.2 \\
\hline 5 & Net profit USD/ha (3-4) & 116.3 & 158.0 & 279.4 & 245.8 & 226.7 & 107.6 \\
\hline 6 & Dominance (D) & & & & D & $\mathrm{D}$ & $\mathrm{D}$ \\
\hline \multicolumn{8}{|l|}{ MRR } \\
\hline 7 & Marginal cost USD/ha & 0.0 & 31.2 & 31.2 & & & \\
\hline 8 & Marginal benefit USD/ha & 0.0 & 41.7 & 121.4 & & & \\
\hline 9 & MRR (8/7) \% & - & 133.6 & 389.1 & & & \\
\hline
\end{tabular}

$\mathrm{MRR}=$ marginal rate of return, $\mathrm{WAE}=$ weeks after emergence

sowing and untreated plot. Generally, promising yield of sesame can be harvested when integrated management of the pest is applied.

\section{Abbreviations}

HuARC: Humera Agricultural Research Center; RCBD: randomized block design; SBN: Sesame Business Network; SWW: sesame webworm; TARI: Tigray Agricultural Institute; WAE: weeks after emergence.

\section{Authors' contributions}

DA participated in the statistical analysis of data and edited the manuscript. IF participated in the design of the study and helped to draft the manuscript. ZG conceived of the study, participated in its design and coordination, performed the statistical analysis and developed the manuscript. All authors read and approved the final manuscript.

\section{Author details}

${ }^{1}$ Tigray Agricultural Research Institute, Humera Agricultural Research Center, P.O. Box 62, Humera, Ethiopia. ${ }^{2}$ Department of Crop and Horticultural Science, Mekelle University, P.O. Box 231, Mekelle, Ethiopia.

\section{Acknowledgements}

Authors would like to acknowledge Tigray Agriculture Research Institute (TARI) and Sesame Business Network (SBN) for the financial support. And deepest gratitude goes to HuARC researchers for the roles played.

\section{Competing interests}

The authors declare that they have no competing interests.

\section{Availability of data and materials}

We declare that whatever data have been used in the manuscript will be kept intact. These data can be made available to anyone who desires to see it from the corresponding author on request.

\section{Consent for publication}

Not applicable.

\section{Ethics approval and consent to participate}

It is to declare that we have all the ethical approval and consent from our organization to participate in research paper writing and submission to any relevant journal.

\section{Declaration}

The authors do hereby declare that, with the exception of references to past and current studies consulted, which have been duly acknowledged, the work presented was carried out from June 2015 to July 2016 in Humera Agricultural Research Center.

\section{Funding}

This work was funded by Tigray Agriculture Research Institute (TARI) and Sesame Business Network (SBN), from its recurrent budgets.

\section{Publisher's Note}

Springer Nature remains neutral with regard to jurisdictional claims in published maps and institutional affiliations.

Received: 10 November 2016 Accepted: 29 May 2018

Published online: 20 June 2018

\section{References}

1. Umar H, Okoye C, Mamman B. Resource use efficiency in sesame (Sesamum indicum L.) production under organic and inorganic fertilizers applications in Keana Local Government Area, Nasarawa State, Nigeria. Res J Agric Biol Sci. 2010;6(4):466-71.

2. FAOSTAT. Food and agriculture organization of the United Nations statistical data; 2015 [cited 2016 22]. http://faostat.fao.org/faostat.

3. Woldesenbet DT, Tesfaye K, Bekele E. Genetic diversity of sesame germplasm collection (Sesamum indicum L.): implication for conservation, improvement and use. Int J Biotechnol Mol Biol Res. 2015;6(2):7-18.

4. Geremew T, et al. Sesame production manual. EIAR/Embassy of the Kingdom of Netherlands, Ethiopia; 2012.

5. Egonyu J, et al. Review of pests and diseases of sesame in Uganda. In: African crop science conference proceedings; 2005.

6. Selemun H. Study on the potential of some botanical powders and nimbecidine for the management of sesame seed bug (Elasmolomus sordidus, Fab.) (Hemiptera: Lygaeidae) in Humera, Northwest Ethiopia; 2011. Addis Ababa, Ethiopia: AAU.

7. Suliman EH, et al. Biology and Webbing behaviour of Sesame webworm, Antigastra catalaunalis Duponchle (Lepidoptera: Pyraustidae). Glob J Med Plant Res. 2013;1(2):210-3.

8. Negash GA. Status of production and marketing of Ethiopian sesame seeds (Sesamum indicum L.): a review. Agric Biol Sci J. 2015;1(5):217-23. 
9. Zenawi G, Dereje A, Ibrahim F. Assessment of Incidence of Sesame Webworm Antigastra catalaunalis (Duponchel) in Western Tigray, North Ethiopia. J Agric Ecol Res Int. 2016;9(4):1-9.

10. Zenawi G, Dereje A, Ibrahim F. Insecticide application schedule to control sesame webworm Antigastra catalaunalis (Duponchel) Humera, North Ethiopia. J Appl Life Sci Int. 2016;8(4):1-8

11. Gebre $H$, et al. Trend and variability of rainfall in Tigray, Northern Ethiopia: analysis of meteorological data and farmers' perception. Acad J Agric Res. 2013:1(6):088-100.

12. Egonyu J, Kyamanywa S, Ssekabembe C. Integration of time of planting and insecticide application schedule to control sesame webworm and gall midge in Uganda. J Appl Biosci. 2009;18:967-75.

13. Ahirwar M, Gupta P, Banerjee S. Bio-ecology of leaf roller/capsule borer Antigastra catalaunalis Duponchel. Adv Bio Res. 2010;1(2):90-104.

14. Karuppaiah V, Nadarajan L. Host plant resistance against sesame leaf webber and capsule borer, Antigastra catalaunalis Duponchel (Pyraustidae: Lepidoptera). Afr J Agric Res. 2013;8(37):4674-80.

15. Reddy PS. Annual report, 1995-96. Directorate of Oilseeds Research; 1996. Hyderabad India.

16. Zerabruk G. Assessment of sesame webworm (Antigastra catalaunalis, (Duponchel) and its preference for Sesame (Sesamum indicum L.) varieties in Western Zone of Tigray, Ethiopia; 2017. Hawasa University.

17. Muzaffar A, et al. Insect pest associated with sesame at Tanato Jam. Pakistan. J Appl Sci. 2002;2(7):723-6.

18. Kumar R, Ali S, Dhoray UC. Incidence of Antigastra catalaunalis, Dup. in different varieties of sesame. Mol Entomol 2012;3(1):15-7.

19. Chadha SS. Effect of some climatic factors on the fluctuation of population of Antigastra catalaunalis. Dup. in oil crops: sesame and sunflower subnetworks proceedings of the joint second workshop; 1990. Cairo, Egypt.

20. Choudhary M et al. Evaluation of sequences of integrated pest management practices against sesame Leaf and Capsule Borer, Antigastra catalaunalis. J Pharmacogn Phytochem. 2017:6(4):1440-4.
21. Mandefro N, et al. Improved technologies and resource management for Ethiopian agriculture training manual; 2009.

22. Karuppaiah V. Eco-friendly management of Leaf Webber and Capsule Borer (Antigastra catalaunalis Duponchel) Menace in sesame; 2014.

23. Abdalla NA, Mohamed $\mathrm{AH}$, The effects of sowing dates and varieties on the infestation with the sesame webworm, Antigastra catalaunalis in sesame. Wad Medani, Sudan: Agriculture Research Corporation; 2014

24. Simoglou B, et al. First report of Antigastra catalaunalis on sesame in Greece. Entomologia Hellenica. 2017;26:6-12.

25. Nayak MK, et al. incidence and avoidable loss due to leaf roller/capsule borer. Ann Plant Soil Res. 2015;17(2):163-6.

26. Wazire NS, Patel Jl. Efficacy of insecticides against sesamum leaf webber and capsule borer, Antigastra catalaunalis (Duponchel). Indian J Entomol. 2015:77(1):11-7.

27. Ali S, Jan A. Sowing dates and nitrogen level effect on yield and yield attributes of sesame cultivars. J Agric. 2014;30(2):203-9.

28. Ali A, et al. Effect of sowing dates and row spacing on growth and yield of sesame. J Agric Res. 2005;43(1):19-26.

29. Ogbonna P, Umar-Shaaba Y. Yield responses of sesame (Sesamum indicum L.) to rates of poultry manure application and time of planting in a derived savannah ecology of south eastern Nigeria. Afr J Biotech. 2011;10(66):14881-7.

30. Yohannes E, Samuel S, Geremew T. Survey and management of sesame webworm Antigastra catalaunalis Duponchel (Lepidoptera: Pyrausitidae) in north Gondar Administrative Zone; 2016. University of Gondar.

31. Muez B. Advanced screening of best performed insecticides for the control of webworm on Sesame at Kafta-Humera Woreda, in regional review; 2015. Humera Agricultural Research Center/TARI.

32. Khalid K. The survey on field insect pests of sesame (Sesamum indicum L.) in east wollega and horo guduru wollega zones, west Oromia, Ethiopia. Int J Entomol Res. 2017;2(3):22-6.
Ready to submit your research? Choose BMC and benefit from:

- fast, convenient online submission

- thorough peer review by experienced researchers in your field

- rapid publication on acceptance

- support for research data, including large and complex data types

- gold Open Access which fosters wider collaboration and increased citations

- maximum visibility for your research: over $100 \mathrm{M}$ website views per year

At $\mathrm{BMC}$, research is always in progress.

Learn more biomedcentral.com/submissions 